\title{
Ontogeny and importance of tidal vertical migrations in the retention of larval smelt Osmerus mordax in a well-mixed estuary*
}

\author{
Réjean Laprise, Julian J. Dodson** \\ Départment de Biologie, Université Laval, Sainte-Foy, Québec, Canada G1K 7P4
}

\begin{abstract}
The retention of larval rainbow smelt Osmerus mordax in the well-mixed, turbid upper estuary of the St. Lawrence River is achieved by active tidal vertical migrations. Time-series analysis of their vertical distribution obtained during two $98 \mathrm{~h}$ sampling series conducted in June and July 1986 revealed that larvae were near the surface during flood tides and nearer the bottom during ebbs. The nature of vertical migration changes with larval size. In June, young larvae concentrated at the surface during flood. Their subsequent descent appears to be a passive sinking and dispersal throughout the water column beginning after the flooding tide attains maximum speed. In July, older larvae concentrated during both flood and ebb and the amplitude of their vertical migration increased. Thus, older larvae use currents more efficiently as reflected by their average position in the estuary, which was farther upstream in July than in June, and by the differential larval size distribution along the estuary. larger larvae being located farther upstream than smaller larvae in July. Passive vertical transport was not responsible for the observed vertical movements as larvae concentrated in surface or bottom layers when mixing of the water column was maximal. Series of hourly average densities calculated from. discrete depth samples revealed cyclic variations associated with tidal advection. As smelt larvae are advected by water masses, their longitudinal distribution was influenced by both active vertical migrations and tidal circulation in the estuary.
\end{abstract}

\section{INTRODUCTION}

Most models of larval fish retention mechanisms in estuaries have been developed for partially mixed or stratified estuaries characterized by 2-layer circulation. In such cases, larvae may exploit landward residual currents along the bottom and seaward surface residual currents by migrating vertically. In temperate estuaries, diel vertical migrations will result in net upestuary transport as larvae will spend more time deep in the water column due to long summer days (Rogers 1940, Norcross \& Shaw 1984).

Few mechanisms have been suggested to explain larval fish retention in well-mixed estuaries. Weinstein et al. (1980) proposed that larvae might use a form of selective tidal stream transport, migrating to the surface during flood tides and to the bottom during ebbs,

\footnotetext{
- Contribution to the programme of GIROQ (Groupe Interuniversitaire de Recherches Océanographiques du Québec).

- Addressee for correspondence
}

so as to minimize net downstream displacement. The amplitude of these tidal migrations might be modified by light conditions. Retention might also be largely passive, negatively buoyant larvae sinking to the bottom at slack tides and being resuspended in the water column by tidal currents (De Wolf 1973). As such, larvae might passively accumulate at the head of estuaries coincident with the zone of longest average advective replacement times (null zone).

The upper part of the St. Lawrence Estuary, between Ile d'Orléans and Ile-aux-Coudres (Fig. 1), is well mixed at the upstream end and partially stratified at the downstream end (Neu 1970, El Sabh 1988). The estuary is highly energetic; tides vary between 3 and $5 \mathrm{~m}$ in height and current speed may reach $250 \mathrm{~cm} \mathrm{~s}^{-1}$, annual mean discharge being $10000 \mathrm{~m}^{3} \mathrm{~s}^{-1}$ (D'Anglejan \& Smith 1973). A series of islands divides the estuary into 3 distinct channels. Due to Coriolis force, the narrow and deep Northern Channel is the major route of flooding tides and fresh water drains preferentially via the shallow and wide Middle and South Channels. A difference of ca 60 min between the tides in the North 


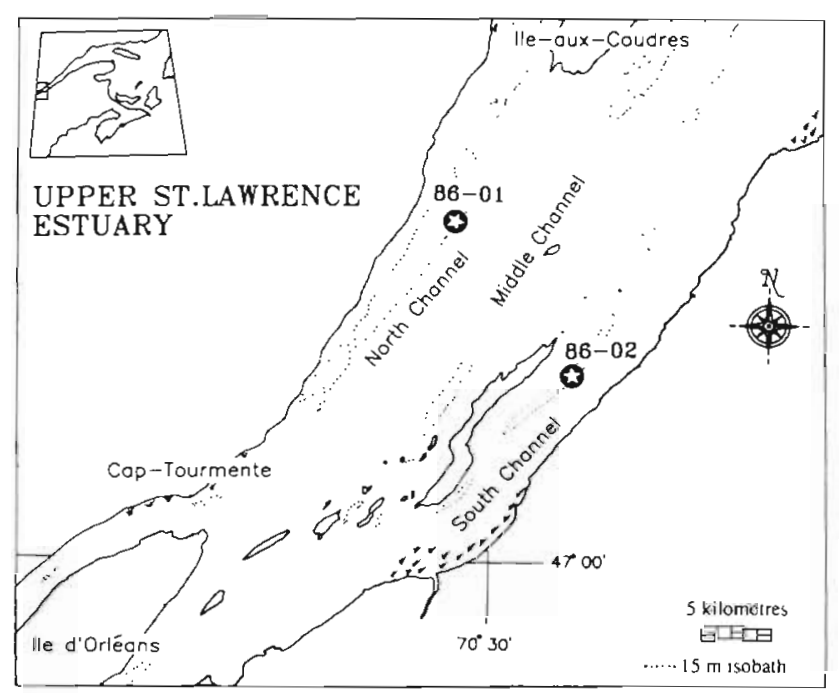

Fig. 1. Locations of Stns 86-01 (sampled on June 6 to 10, 1986) and 86-02 (sampled on July 6 to 10, 1986) in the Upper St. Lawrence Estuary

and South Channels contributes to the formation of strong transversal currents upstream and downstream of the central islands (D'Anglejan \& Ingram 1976, Ouellet \& Cerceau 1976, Ouellet \& Trump 1979). Thus, this part of the St. Lawrence Estuary is characterized by cyclonic circulation which, in addition to the presence of a null zone (Dodson et al. 1989), contributes to retain suspended particulate matter inflowing from rivers and salt marshes along the estuary. In fact, this area is highly turbid (50 to $>200 \mathrm{mgl}^{-1}$ year-round in the turbidity maximum; D'Anglejan 1981) and the concentration of suspended particulate matter is always greater than either further upstream or downstream (D'Anglejan \& Smith 1973, Silverberg \& Sundby 1979 , D'Anglejan 1981). The turbidity zone extends from Cap-Tourmente to Ile-aux-Coudres in the Northerm Channel and is located slightly downstream in the other channels due to the nature of the water circulation (Kranck 1979). The maximum of turbidity is situated around Cap-Tourmente and moves upstreamdownstream following tides and river discharge. Negatively buoyant particles sink during slack waters and are resuspended by tidal currents in the bottom layer. They are subsequently transported upstream by landward residual currents and entrapped in the null zone. Cyclonic circulation and the constant input of allochtonous matter from rivers, salt marshes and dredging activities are other factors accounting for the presence of this permanent turbidity zone (Kranck 1979, D'Anglejan 1981, Lucotte \& D'Anglejan 1986).

Rainbow smelt Osmerus mordax is an anadromous species that constitutes the major part of the larval fish community of the Upper St. Lawrence Estuary (Able 1978, Courtois et al. 1982). Smelt spawn in the spring following ice breakup in the small rivers situated along the south shore of the estuary (Fréchet et al. 1983) and larval smelt are subsequently put into circulation in the estuary around mid-May (Ouellet \& Dodson 1985a, b). Larvae are then retained in the upper estuary, where they are associated with the turbidity zone for ca 2 mo, just until metamorphosis (Dodson et al. 1989).

Rogers (1940) proposed that the retention of smelt larvae in the upper part of the Miramichi Estuary (New Brunswick, Canada) was due to daily vertical migrations enhanced by the negative phototaxis of larvae. Ouellet \& Dodson (1985a) and Dodson et al. (1989) suggested that larvae use a form of selective tidal stream transport to stay in the turbidity zone. In addition, Ouellet \& Dodson (1985a) proposed that the cyclonic circulation could interact with the vertical migrations to help young larvae remain in the upper estuary. However, vertical migration behavior was not a primary objective of those studies and the sampling series were not long enough to reach meaningful conclusions concerning vertical migration patterns.

The major objective of the present research project was to define the mechanisms responsible for the retention of larval smelt in the well-mixed region of the Upper St. Lawrence Estuary. Given the physical characteristics of the estuary and results to date, several mechanisms were possible including purely passive retention based on cyclonic circulation and active mechanisms based on tidal vertical migrations. The second objective was to describe the ontogeny of larval smelt retention. In the case of active vertical movements of larvae, our final objective was to identify physical cues responsible for signalling vertical migration.

\section{MATERIAL AND METHODS}

Two sampling series were conducted in summer 1986: at the beginning of June, shortly after the arrival of larvae in the estuary, and in early July, 1 mo after the establishment of smelt larvae in their feeding area.

First, a series of upstream-downstream transects were sampled in the 3 channels of the estuary to localize the center of maximum larval density. Once localized, a fixed anchor station was occupied for $98 \mathrm{~h}$ in the Northern Channel in June (Stn 86-01) and $97 \mathrm{~h}$ in the Southern Channel in July (Stn 86-02; Fig. 1). The water column, measuring ca $21 \mathrm{~m}$ at low tide, was divided into 3 equal depth strata $(0$ to $7 \mathrm{~m}, 8$ to $14 \mathrm{~m}$ and 15 to $21 \mathrm{~m}$ ) and an Aandera Mark II current meter was anchored in the middle of each depth stratum $(3.5,10.5$ and $17.5 \mathrm{~m}$ from the bottom) to measure conductivity, temperature and current speed and direction at 2 min intervals over the sampling period. At the beginning of each hour of the sampling series, 2 water samples were 
taken in the middle of each depth stratum with Niskin bottles for turbidity measurements. Turbidity levels in NTU (Nephelometric Turbidity Units) were determined using a model 2100A Hach turbidity meter.

Larval fish were sampled using a Tucker trawl (1.09 $\times 1.19 \mathrm{~m})$, equipped with an opening-closing device and a $0.5 \mathrm{~m}$ standard net $(0.51 \mathrm{~mm}$ mesh). A General Oceanic flowmeter was fitted at the mouth of the gear to measure the filtration rate. Each depth stratum was sampled once per hour. The nets were towed against the current at a speed of 2 or 3 knots by a $21 \mathrm{~m}$ vessel (MV 'Rigolet'). Each tow lasted $8 \mathrm{~min}$ and filtered on average $600 \mathrm{~m}^{3}$ of water.

Larvae were preserved in $4 \%$ buffered formalin (Markle 1984). Samples containing 200 larvae or less were completely sorted in the laboratory. Samples containing more than 200 larvae were subsampled using a Motoda splitter (Van Guelpen et al. 1982). Fifty larvae were randomly chosen from each sample for length measurements. Larvae were placed in a scaled petri dish and photographed using 25 ASA Kodak technical pan film 2415. Films were developed and negatives were projected on a digitalized table (HIPAD) connected to a computer. The total length of the larvae were measured by this system to the nearest $0.01 \mathrm{~mm}$.

Physical and biological data were analysed by timeseries analysis (Legendre \& Legendre 1984). First, longterm trends were systematically calculated for each series using polynomial regressions. Most of these trends were not interpretable. They were subsequently removed from original data to make the time series stationary. Residues were then smoothed by an order 3 unweighted moving average to reduce the white noise. Autocorrelation functions were calculated on the raw and smoothed residues to find the periods of observed cyclic fluctuations. The period was then taken off by constructing a bandpass filter (Hamming 1977) using the BMDP statistical software (Thrall \& Engelman 1985) and residues analysed for other existing periods. Crosscorrelation functions were used to compare series. This method describes the temporal relations between two series and allows the interpretation of fluctuations in terms of variations in associated series. Finally, univariate statistics were made according to Scherrer (1984).

\section{RESULTS}

\section{Hydrodynamics}

Sampling was performed during spring-tide conditions at both stations. Tides were characterized by an asymmetry in the amplitude, duration and current speed between flood and ebb phases for a given tide, and between tides for a given day. In June, flood tides

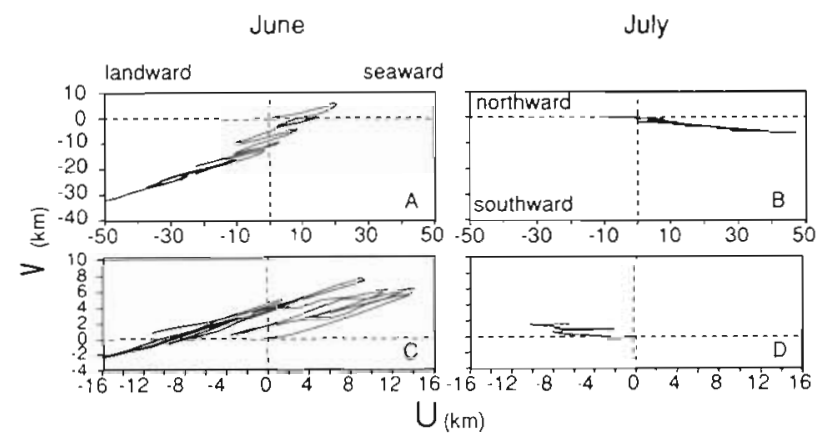

Fig. 2. Progressive vector diagrams illustrating the net residual displacement of water masses in June (Stn 86-01) and July (Stn 86-02) for the surface and bottom layers. A, B: surface layer $(3.5 \mathrm{~m}) ; \mathrm{C}, \mathrm{D}$ : bottom layer $(17.5 \mathrm{~m})$. U, V longitudinal and transverse tidal current vectors, respectively

were always longer than ebbs. In contrast, ebbs were longer than floods in July. For both stations, highest high water was in the morning.

Fig. 2 shows the progressive vector diagrams calculated for the surface and bottom layer for each station over the sampling period. In June, the displacement of the water masses was landward across the water column, attaining $49 \mathrm{~km}$ and $10 \mathrm{~km}$ after $98 \mathrm{~h}$ in the surface and bottom layers respectively. Net residual displacement measured in the cross-channel axis of the estuary was $32 \mathrm{~km}$ southwest in the surface layer and $0.5 \mathrm{~km}$ northeast in the bottom layer. Strong northeasterly winds attaining 25 to 30 knots during the sampling period probably accentuated the net residual displacement of surface water masses. In July, the net residual displacement was seaward $(38 \mathrm{~km})$ and southward $(6 \mathrm{~km})$ in the surface layer after $97 \mathrm{~h}$. In the bottom layer, the net residual displacement of water masses was landward $(6.5 \mathrm{~km})$ and northward $(1.6 \mathrm{~km})$ after $36 \mathrm{~h}$. Only $36 \mathrm{~h}$ of bottom data were available because of the blockage of the current meter rotor by detritus. The upstream or downstream displacement of water masses in the surface layer during one flood or one ebb was $18.8 \mathrm{~km}$ (varying between 12 and $26 \mathrm{~km}$ ) in June and $13.5 \mathrm{~km}$ (varying between 9 and $20 \mathrm{~km}$ ) in July, averaged over 6 tidal cycles.

T-S diagrams (Fig. 3) show the effect of the tidal water displacement at the anchor stations during each series. For both stations, salinity and temperature make a regular movement from warm and fresh water at low tide to cold and more saline water at high tide. Salinities varied from 6.10 to $15.46 \mathrm{~g} \mathrm{~kg}^{-1}$ in June and from 0.03 to $6.67 \mathrm{~g} \mathrm{~kg}^{-1}$ in July. In addition, movement of water masses toward warmer and less saline conditions at the end of each series indicates that the salinity front was moving downstream during both sampling periods. This is probably related to the end of spring tide conditions.

The vertical distribution of isopycnes in June indi- 


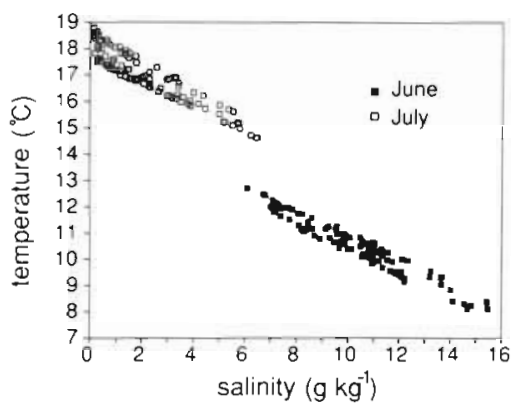

Fig. 3. Temperature-Salinity regimes observed at $10.5 \mathrm{~m}$ at Stns 86-01 (June 1986) and 86-02 (July 1986)

cates that the water column was well-mixed during flood and ebb tides (Fig. 4). At slack water, the water column was partially stratified, the difference of density $\left(\sigma_{t}\right)$ between 3.5 and $17.5 \mathrm{~m}$ reaching a maximum value of 6 at the end of low slack water. This maximum was reached when flooding began in the bottom layer earlier than in the surface layer. In July, malfunction of the temperature probe for the surface current meter did not permit us to evaluate the stratification for the whole water column. However, the location of the station (almost in fresh water), the instantaneous salinity gradient (always weak) and results from other studies (e.g. Neu 1970) led us to conclude that the water column was well-mixed over the entire sampling period.

The Richardson number, $\hat{\mathrm{Ri}}$, is a good estimator of the vertical dynamic stability of the water column as it integrates current velocities with density index (Neumann \& Pierson 1969). Ri was calculated according to Fortier \& Legendre (1979) between 3.5 and $17.5 \mathrm{~m}$ in June and showed that the water column was very turbulent as its values were always under 3 (Fig. 5). In addition, the flooding tide was the period of greatest mixing. The destabilisation of the water column during the strongest floods was generally greater than during the weakest floods. Ri was not calculated for the July sampling period because of the malfunction of the current meter.

Tuibidity (Fig. 5) varied from 8 to 68 NTU in June and from 8 to 140 NTU in July. Turbidity was generally higher in the bottom layer and varied in a $12.4 \mathrm{~h}$ period at all depths. Cross-correlation functions between each depth stratum showed that turbidity variations were synchronized and probably more related to tidal advection of the horizontal turbidity maximum than to a resuspension of sediments by tidal currents. Highly turbid waters were associated with low slack waters in June and July. We concluded that both stations were located slightly downstream of the turbidity maximum. In addition, the long-term trend showed a constant increase of turbidity during the sampling period in July, probably related to the downstream movement of the salinity front and the associated turbidity maximum. A $6 \mathrm{~h}$ cycle related to maximum tidal current velocities was superimposed on the $12.4 \mathrm{~h}$ cycle in the bottom layer at both stations, indicating resuspension of sediments near the bottom.

Time series of tidal current velocities are illustrated in Fig. 5 to show the relations with $\hat{R i}$ and turbidity fluctuations. Note that the current speed was considerably less in July.

\section{Horizontal advection of smelt larvae}

Average densities of smelt larvae were $3052 \pm 2175$ per $1000 \mathrm{~m}^{3}$ in June and $932 \pm 768$ per $1000 \mathrm{~m}^{3}$ in July. Series of hourly average densities, calculated from the 3 discrete-depth samples, show cyclic variations of $6,12.4$ and $24.8 \mathrm{~h}$ periods for both stations (Fig. 6). In June, the maxima of the predominant $6 \mathrm{~h}$ cycle were associated with the beginning of the flood and ebb. In July, there was an alternation between the 6 and the $12.4 \mathrm{~h}$ periods. The first is correlated with the end of flood and ebb of the higher high water cycle, and the second is associated with the low slack water of the lower high tide cycle. These cyclic abundance fluctuations may be associated with the tidal advection of smelt larvae. Horizontal displacement of larvae, possibly distributed as a patch, may create cyclic abundance variations with a tidal rhythm at a fixed anchor station.

The hourly series of average length of larvel smelt observed in July also indicates tidal advection. The series presents regular cyclic fluctuations (Fig. 6) of 12.4 and $24.8 \mathrm{~h}$ periods which are correlated with the longitudinal vector of tidal current (U). The crosscorre-

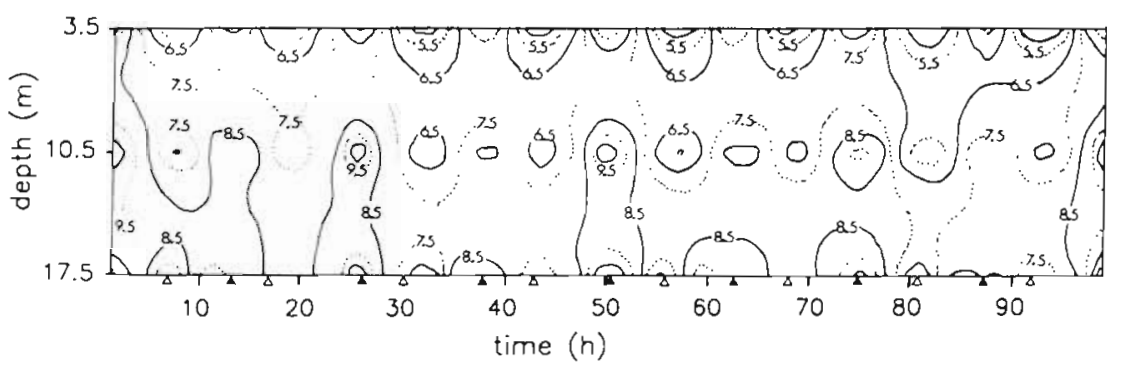

Fig. 4. Time-depth variations of the density $\left(\sigma_{t}\right)$ at Stn 86-01 (June 1986). ( $\angle$ ) Low slack water; (4) high slack water 


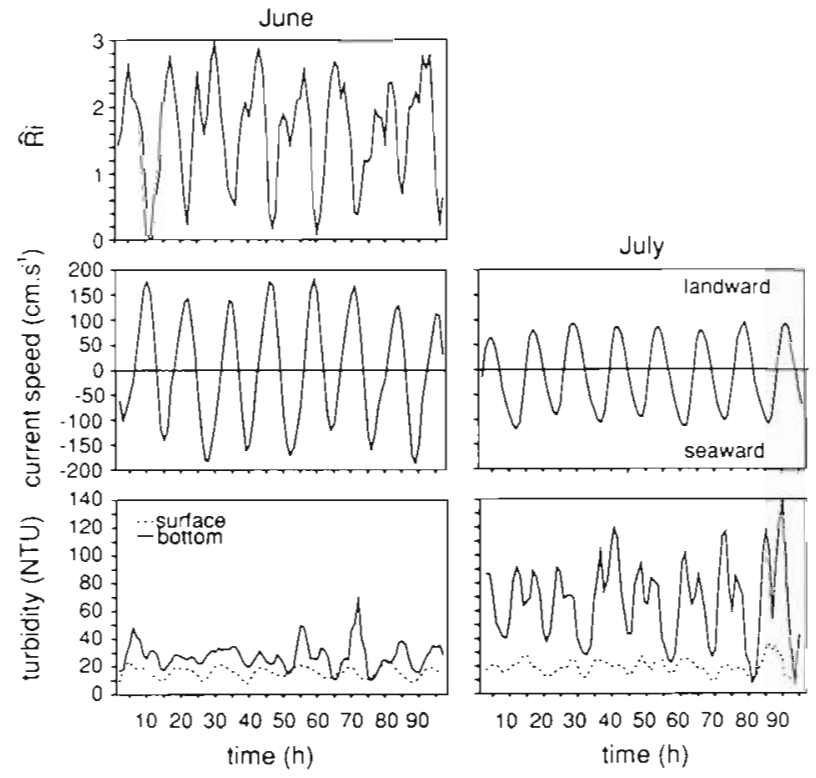

Fig. 5. Time series of the Richardson number ( $\mathrm{Ri}$ ), the longitudinal current speed (U) in the middle layer $(10.5 \mathrm{~m})$, and the surface $(3.5 \mathrm{~m})$ and bottom $(10.5 \mathrm{~m})$ turbidity at Stns $86-01$ (June 1986) and 86-02 (July 1986). Polynomial long-term trends were removed from the original data and residues were filtered by an order 3 unweighted moving average

lation function indicates that small larvae were associated with high slack water and large larvae with low slack water. Thus, it appears that small larvae were distributed farther downstream than larger larvae. The $24.8 \mathrm{~h}$ cycle corresponds to the asymmetry of the tidal cycle; the length of the longitudinal displacement of larvae being large or small depending on water displacement. There was also a significant ascendant trend in the length series. This trend may be due to the retreat of the salinity front during the sampling series. Like the turbidity maximum, the longitudinal distribution of smelt larvae must have moved downstream. As a result, mean larval length increased as larger larvae were found on average further upstream than smaller larvae. A similar analysis conducted for the June sampling series revealed no significant differential distribution of smelt according to size (Fig. 6).

\section{Abundance, length and avoidance}

The tidal advection of larvae and their differential length distribution makes the evaluation of daytime net avoidance problematic. Standard comparisons between daytime-nighttime abundance and length are biased. The dark period at this latitude lasts only ca $6 \mathrm{~h}$ in June and July and coincided with the ebbing-low slack water' part of the lower high tide cycle. As daytime samples corresponded to the higher high water cycle plus the 'flooding-high slack water' part of the lower high tide cycle, the 2 sets of data are not comparable. To minimize this problem, we compared samples which were caught during the same part of the tidal cycle. However, as the tidal advection follows a $24.8 \mathrm{~h}$ cycle, comparisons of abundance and length made between successive ebb tides remain biased.

In June, there was no significant differences in the mean daytime-nighttime densities (Table 1). However, larvae were significantly smaller during the day. Smelt larvae were divided between 3 length classes and daytime-nighttime densities were calculated for each depth strata sampled for each class. Analysis performed on these classes revealed that there was a significant increase in abundance of larvae smaller than $15 \mathrm{~mm}$ in the surface layer during the day (Fig. 7). No significant differences were observed in the middle and bottom layers for all length classes and for larvae longer than $15 \mathrm{~mm}$ in the surface layer. We conclude that the increase in the numbers of small larvae in the surface layer, and the concomitant decrease of average length during daytime ebbs, was due to an input of small larvae from upstream.

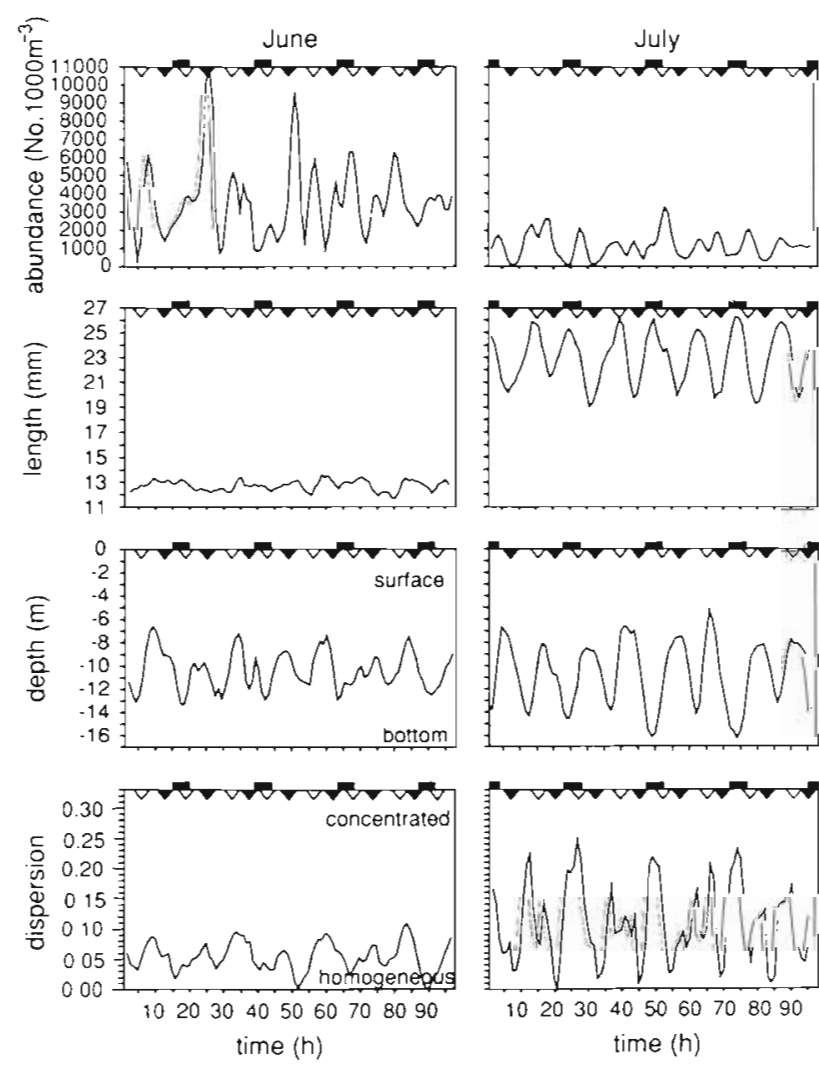

Fig. 6. Osmerus mordax. Time series of abundance, mean length, mean depth and dispersion of smelt larvae at Stn 86-01 (June 1986) and 86-02 (July 1986). Polynomial long-term trends were removed from the original data and residues were filtered by an order 3 unweighted moving average. (1) High slack waters; ( $\Delta$ ) low slack waters; dark bars: night periods 
Table 1. Osmerus mordax. Average daytime-nighttime abundance and length of smelt larvae at Stns 86-01 (June 1986) and 86-02 (July 1986), Upper St. Lawrence Estuary. Sample sizes are in brackets. ("Mann and Whitney test: $p=0.0039, \cdots$ KolmogorovSmirnov test: $p<0.05$ \}

\begin{tabular}{|c|c|c|c|c|c|}
\hline \multirow[t]{2}{*}{ Station } & \multicolumn{2}{|c|}{ Abundance (No. $1000 \mathrm{~m}^{-3}$ ) } & \multicolumn{3}{|c|}{ Length (mm) } \\
\hline & Day & Night & Day & & Night \\
\hline June & $\begin{array}{c}3139 \pm 2192 \\
(72)\end{array}$ & $\begin{array}{c}2717 \pm 1130 \\
(72)\end{array}$ & $\begin{array}{c}12.31 \pm 2.31 \\
(4427)\end{array}$ & $\cdots$ & $\begin{array}{c}12.65 \pm 2.38 \\
(4049)\end{array}$ \\
\hline July & $\begin{array}{c}1002 \pm 704 \\
(72)\end{array}$ & $\begin{array}{c}859 \pm 908 \\
(72)\end{array}$ & $\begin{array}{c}23.50 \pm 3.83 \\
(3765)\end{array}$ & & $\begin{array}{c}23.55 \pm 3.87 \\
(3712)\end{array}$ \\
\hline
\end{tabular}

In July, there were significantly more larvae during the day than at night, while larval length was not significantly different (Table 1). Again, an analysis performed on 3 length classes revealed that there was an increase of abundance in the surface layer during the day except for larvae smaller than $20 \mathrm{~mm}$ (Fig. 7).

Thus, it appears that smelt larvae were unable to avoid the net during the day as length frequency distributions did not change in the surface layer in July. This is not surprising given the high level of turbidity prevailing in the area. At both stations, there was an input of larvae from upstream surface waters during daytime ebbs.

\section{Growth}

The average sizes of smelt larvae recorded in June and July were $12.60 \pm 2.30 \mathrm{~mm}$ and $22.56 \pm 4.02 \mathrm{~mm}$ respectively. The length frequency distribution of lar-

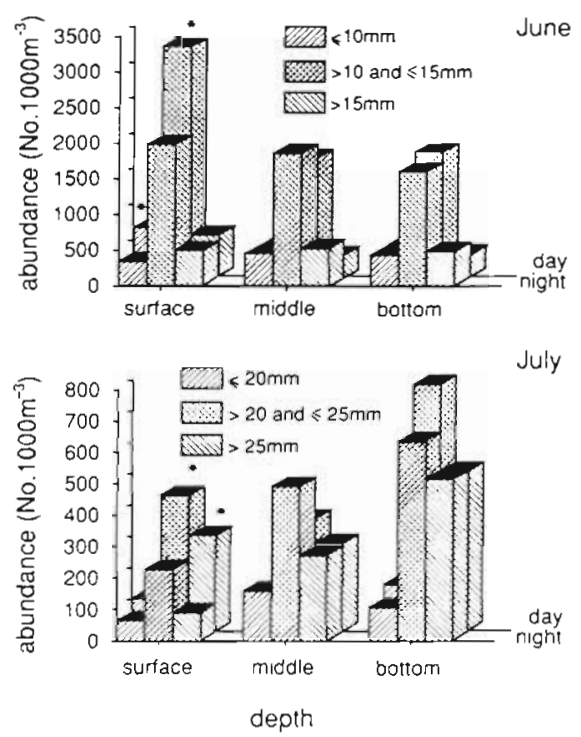

Fig. 7. Osmerus mordax. Mean larval densities of 3 size classes in the surface $(0$ to $7 \mathrm{~m})$, middle ( 8 to $14 \mathrm{~m}$ ) and bottom (15 to $21 \mathrm{~m}$ ) layers during daytime and nighttime periods in June (Stn 86-01) and July (Stn 86-02). Stars indicate significant differences between daytime and nighttime abundances (Wilcoxon-Mann and Whitney test, $p<0.05$ ) vae sampled in June is almost normal (Fig. 8) becoming more flattened in July The average growth rate calculated from June to July was $0.33 \mathrm{~mm} \mathrm{~d}^{-1}$.

\section{Vertical distribution}

Vertical distribution of smelt larvae was documented by studying changes in the center of mass of larvae (mean depth; Fortier \& Leggett 1982) calculated for each hour (Fig. 6). In June, the mean depth of larvae was $9.42 \pm 1.51 \mathrm{~m}$ from the surface varying from 6.34 to $13.80 \mathrm{~m}$ with no significant differences between different size classes of larvae (Kruskal-Wallis test, $p=0.26$ ). In July, the mean depth of larvae was $10.88 \pm 2.82 \mathrm{~m}$ varying from 5.38 to $16.73 \mathrm{~m}$. The mean depth was significantly different between the 2 mo, larvae in July occupying deeperwater ( 1 -tailed test, $Z_{\text {obs }}=4.506>Z_{0.05}$ $=1.645$ )

Autocorrelation functions conducted on the center of mass series revealed significant cycles of 12.4 and $24.8 \mathrm{~h}$ for both stations (Fig. 9). Crosscorrelation analysis with the longitudinal vector of tidal current showed that, in June, larvae were closer to the surface at the maximum of flood tide currents and deeper in the water column during the maximum of ebbing currents (Fig. 9). Larvae were found at an intermediate depth during slack tides. The correlation values were higher in July and the pattern of vertical movements of the center of mass was more precise with a larger amplitude (Fig, 6). The $24.8 \mathrm{~h}$ cycle was related to the asymmetry of the tidal cycle. During the stronger flood tides, the displacement of larvae towards the surface seems to be less for both cruises. These observations were similar for all size classes, suggesting that vertical migratory behavior begins very shortly after larvae leave their natal tributaries.

\section{Vertical dispersion}

The dispersion of smelt larvae throughout the water column was estimated by calculating the variance between the relative proportions of larval abundance in 
Fig. 8. Osmerus mordax. Relative length frequency distribution of smelt larvae in June (Stn 86-01) and July (Stn 86-02)

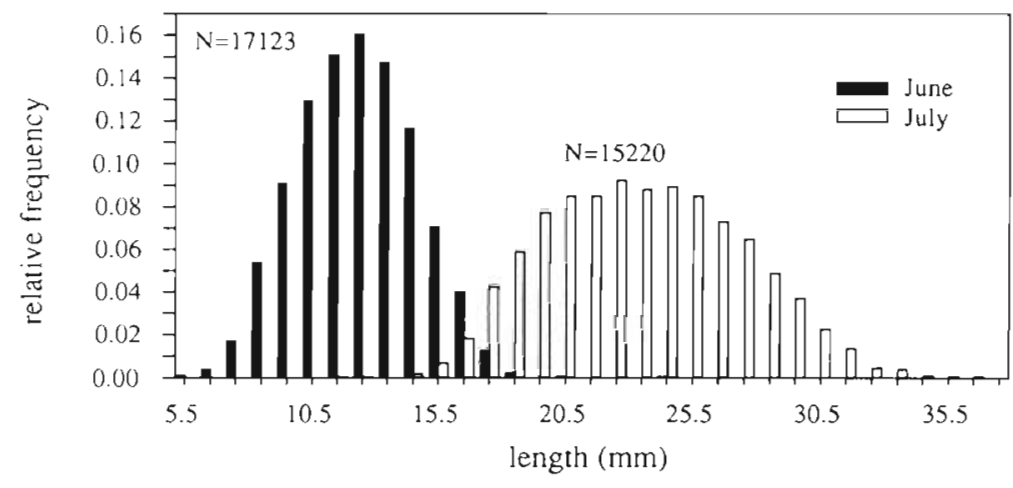

In July, there was a $6 \mathrm{~h}$ cycle which, once crosscorrelated with the tidal current speed, was associated with flood and ebb. Larvae were more concentrated in the surface and in the bottom layers when current speeds were maximum. The $12.4 \mathrm{~h}$ period was associated with low slack water, larvae being more concentrated at that time than during high slack water. The $24.8 \mathrm{~h}$ period followed the same pattern as in June.

\section{DISCUSSION}

Our results on the hydodynamics at both stations are in agreement with previous studies in the Upper St. Lawrence Estuary. Stn 86-01 was located in the Northern Channel which is the preferred route for flooding tides. Hence, flood tides were longer than ebbing tides and the residual displacement of water masses was landward throughout the water column. Stn 86-02, located in the southern channel, was preferred by the ebbing tides, ebbs being always longer than floods. There was a net outflowing current in the major part of weak floods than during the strong floods.
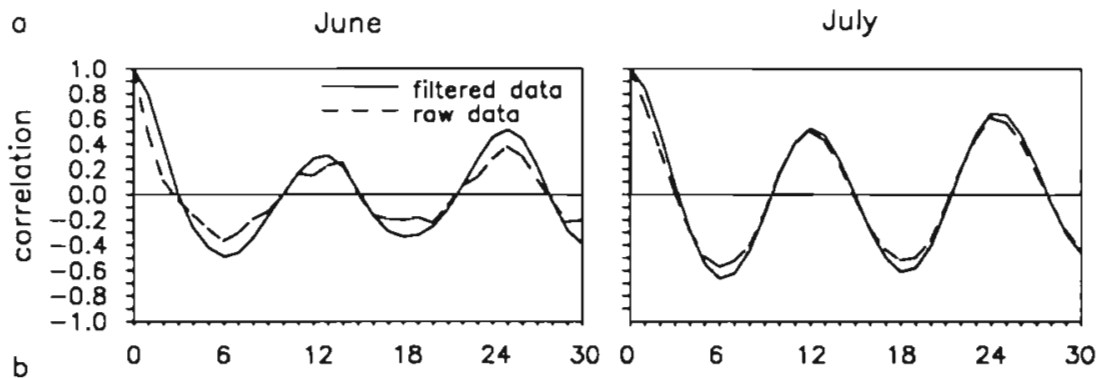

Fig. 9. Osmerus mordax. (a) Autocorrelation functions of the time series of the average vertical position of smelt larvae. (b) Crosscorrelation functions between the time series of the average vertical position of smelt larvae and the longitudinal tidal current speed (U). Raw data: residues of the polynomial regression; filtered data: residues of the polynomial regression smoothed by an order 3 unweighted moving average
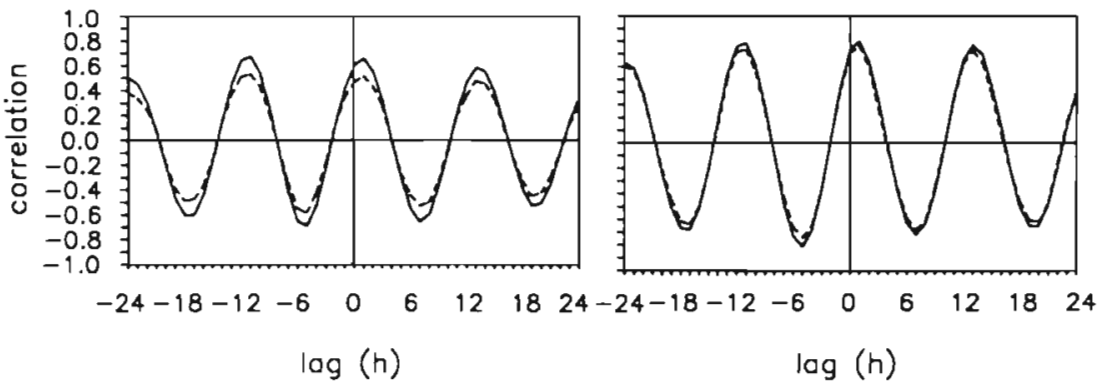
the water column and a landward compensatory current near the bottom. These results are in agreement with those reported by Soucy et al. (1976).

There was a significant cross-channel movement of water masses at both stations and the direction of the movement was predictable by the Coriolis force, except for surface waters in June. The southern movement of surface water at Stn 86-01 might have been induced by the presence of a constant northeasterly wind during the sampling period. This illustrates that the circulation pattern in this part of the estuary may be greatly affected by meteorological events.

Both stations were well-mixed most of the time, the station in June becoming slightly stratified at the turn of the tide. Both stations were characterized by highly turbid water. The concentration of suspended particulate matter was higher in the bottom layer and increased during floods and ebbs due to a resuspension of bottom sediments by tidal currents.

Variations in larval abundance observed at a fixed station in the estuary are caused by the tidal displacement of water masses over distances of 9 to $26 \mathrm{~km}$ (Fig. 2). Our sampling and that of Dodson et al. (1989) indicate that smelt larvae are distributed as a patch in the estuary and that larvae at the center of the patch are more concentrated than at the edges. The conceptual model presented in Fig. 10 simulates the tidal advection of this patch. The appearance of the patch center under the boat depends on the location of the patch in the estuary relative to the boat and on the type of tide running the pattern. In Situation $A$, the location of the patch is on average under the boat. In Situation $B$, the average position of the patch is upstream of the station. These 2 situations correspond to our observations, with the patch crossing the station every flood and ebb in June (Situation A), and crossing the station

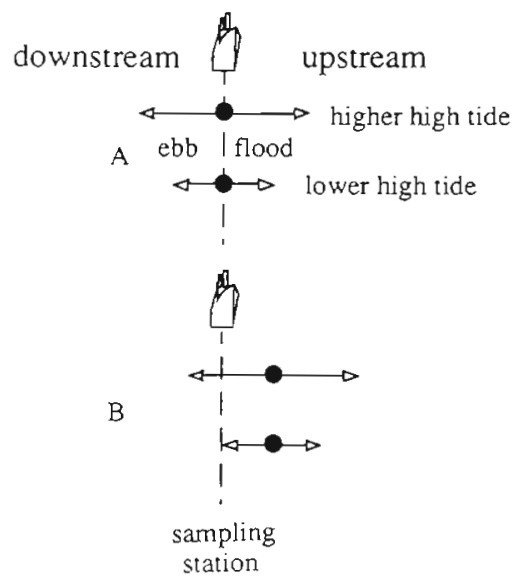

Fig. 10. Schematic representation of the effect of the tidal advection of a patch of larvae on the sampling at a fixed anchor station. Dark circles: center of the larval patch; arrows: tidal displacement. See text for explanation. only during floods and ebbs of the higher high water cycle in July, stopping near the station during lower low slack water when the longitudinal displacement of water is less (Situation B).

The vertical distribution of smelt larvae in the wellmixed part of the St. Lawrence Estuary conformed to hypotheses of retention based on tidal vertical migrations. Larvae were found near the surface during floods and nearer the bottom during ebbs. Thus, they take advantage of maximum surface landward currents during floods and reduce their downstream transport by using slower deep currents during ebbs. These results support those of Ouellet \& Dodson (1985a) and Dodson et al. (1989). But they are in contradiction with the conclusions of Rogers (1940) concerning the retention of smelt larvae in the Miramichi River. By comparing nighttime and daytime samples, he proposed that larvae were retained in the upper estuary by migrating to the surface layer at night and staying in the bottom layer during the day. This behavior, associated with longer daytime periods, results in a net up-estuary transport when the water circulation is a 2-layer type. However, his analysis did not take into account the tidal state during the sampling periods. A re-examination of his data revealed that the vertical distribution of smelt larvae corresponds to the predictions of the hypothesis of tidal vertical migrations (Table 2). All daytime samples were taken during ebbing tide, when larvae are nearer the bottom. One nighttime sample was taken during the flooding tide and corresponds to a larval concentration in the surface layer Finally, only 6 larvae were caught (from 2 tows of 30 min duration) in the last night sample which is inadequate to conclude that larvae were in the surface layer during night ebbing tides. Thus, we propose that tidal vertical migratory behavior may be typical of Atlantic coast anadromous smelt populations and may be very important in the isolation mechanisms of these populations.

Although smelt larvae migrate vertically regardless of size, the nature of vertical migration changes with larval size. In June, young larvae concentrated at the surface during floods. Their descent appears to be a passive sinking and dispersal throughout the water column beginning after the flooding tide attains maximum speed. In July, older larvae concentrated during both flood and ebb and the amplitude of their vertical migration increased. This might be related to the development of the swim bladder and the locomotor apparatus. Thus, older larvae use currents more efficiently as reflected by their average position in the estuary, which was further upstream in July than in June, and by the differential larval size distribution along the estuary, larger larvae being located further upstream than smaller larvae in July. The last observation was also reported by Dodson et al. (1989). 
Table 2. Osmerus mordax. Number of smelt larvae reported by Rogers (1940, Table III, p. 168) in surface (0 to 2 m) and bottom (5 to $11 \mathrm{~m}$ ) layers in the Miramichi Estuary during summer 1918 . Larvae were caught by a $76 \mathrm{~cm}(0.5 \mathrm{~mm}$ mesh) plankton net. Tows were of 30 min duration. Tidal states were calculated according to Dawson (1917)

\begin{tabular}{|lccccc|}
\hline Date & Station & \multicolumn{2}{c|}{$\begin{array}{c}\text { Number of larvae } \\
\text { Surface }\end{array}$} & Bottom & Time (h) \\
& & 112 & 2500 & Tidal state \\
June 4 & 81 & None & 18 & $15: 45$ & Ebbing tide \\
June 4 & 75 & 20000 & 40000 & $17: 30$ & Ebbing tide \\
June 7 & 82 & None & Several hundred & $10: 25$ & Ebbing tide \\
July 1 & 100 & 850 & 200 & $23: 55$ & Ebbing tide \\
July 2 & 94 & 4 & 2 & $22: 10$ & Flooding tide \\
July 26 & $76 \mathrm{~A}$ & & & & Ebbing tide \\
\hline
\end{tabular}

It is unlikely that the water circulation at the stations could have been responsible for the observed vertical movements of smelt larvae. The concentration of larvae in surface or bottom layers occurred when the mixing of the water column was maximal for both cruises. In the case of the bottom sediments, resuspension occurred during maximum currents of either flooding or ebbing tides. But the vertical distribution of larvae during ebbs in July did not seem to be affected by ebbing currents as they were not 'resuspended', but concentrated in the bottom layer. Moreover, the mixing of the water column during floods and ebbs tends to homogenize the distribution of particles throughout the water column. This may be responsible for the homogeneous dispersion of small larvae in June throughout the water column during ebb. However, in June, during flood, and in July, during both flood and ebb, larvae must have resisted this tendency in order to concentrate in a particular stratum of the water column. Thus, it appears that larvae do not behave like passive particles and that the vertical ascent, for both months, and the descent, in July, were most definitely due to an active migration.

These observations also explain why larvae were more concentrated and higher in the water column during the flood of the lower high tide. As turbulence was greater during the higher high tide, larvae may have been less able to resist dispersion. This could also explain the appearance of greater numbers of larvae in surface waters during daytime ebbs. These times corresponded to the strongest ebbing tides. Larvae were more dispersed in the water column (Fig. 6) due to stronger mixing during these periods. Consequently, there were more larvae in the surface layer and, as they are subject to advection by water masses, they were transported farther downstream by faster surface currents. In June, the small size of larvae arriving from upstream may be related to the end of hatching. Ouellet \& Dodson (1985a) have shown that larvae hatch at night and are put into circulation in the estuary only during daytime, following high tides in the natal rivers.
In July, the large size of larvae appearing in surface waters during daytime ebbs may reflect the differential size distribution of larvae along the estuary, larvae from upstream being on average larger than those located downstream.

The vertical migrations of larvae are not associated with the vertical distribution of their food or their predators. Parallel studies have demonstrated that food organisms are abundant at all depths throughout the area and that smelt feed successfully regardless of depth on a variety of prey (Laprise \& Dodson unpubl., Dauvin \& Dodson unpubl.). In the case of potential macrozooplanktonic predators, they are found downstream of the turbidity zone (Courtois et al. 1982, Dodson et al. 1989). In addition, analysis of the stomach contents of adult smelt and tomcod, which constitute the major part of the fish community in this part of the estuary, revealed little or no predation on larvae (Laprise $\&$ Dodson unpubl.). Thus, the adaptive significance of this pattern of vertical distribution appears to be associated with the control of horizontal larval distribution and their retention in the upper part of the St. Lawrence Estuary.

Retention in a turbidity zone offers advantages of refuge from predation and access to an abundant food resource (Blaber \& Blaber 1980, Bruton 1985). Potential food in the form of calanoid copepods (particularly Eurythemora affinis) and young stages of mysids (particularly Neomysis americana) are 3 to 10 times more abundant in this part of the estuary than either upstream or downstream (Bousfield et al. 1975). In addition, turbidity might enhance the feeding of smelt larvae as was demonstrated for herring larvae (Boelhert \& Morgan 1985). The observations of growth rates along the estuary confirm these potential advantages. As proposed by Simoneau (1986), the growth of smelt larvae seems to follow an upstream-downstream gradient and to be maximum in the turbidity zone Lowest values of growth were always found near or downstream of Ile-aux-Coudres (Able 1978, Fortier \& Leggett 1982, Simoneau 1986). Our value $(0.33 \mathrm{~mm}$ 
$\mathrm{d}^{-1}$, which was calculated from June to July in the turbidity zone, is greater than values of $0.10,0.18$ and $0.24 \mathrm{~mm} \mathrm{~d}^{-1}$ reported by previous studies for the same time of the year downstream of our stations (Able 1978, Simoneau 1986). These observations suggest that the upper estuary offers extremely good conditions for the growth of this population.

We may at present only speculate about the nature of the cues which signal vertical migrations. Such cues may include olfactory discrimination of from-land or from-sea currents, detection of flow direction or flow reversal, turbulence variations and induced electric fields in the water (McCleave \& Kleckner 1982). The resuspension of bottom sediments during fast tidal currents may also act as a signal.

It is unlikely that the olfactory discrimination and the current detection hypotheses are applicable in the present situation as smelt larvae always stay in the water column. Thus, they move vertically in the same body of water with no visual or tactile references. They might be able to detect the increase of turbidity in the bottom layer during ebb, but this increase is not transmitted to the surface layer. Thus, it could signal the ascent of larvae but not the descent. In addition, larvae observed in June were dispersed almost homogeneously during ebb with only a small proportion of the population in the bottom layer.

Turbulence and induced electric fields are 2 features which could be detected in the whole water column everywhere in tidal waters. In June, in the Northern Channel, turbulence was maximal during flooding tides and corresponded to the active ascent of young larvae. Turbulence was minimal during slack water and increased slightly during ebbs. Induced electric fields could act in the same way as turbulence, as both are associated with tidal current speed. Cues responsible for signalling active vertical migrations and the possible role of endogenous circatidal activity rhythms (Wippelhauser \& McCleave 1988) remain to be verified.

Acknowledgements. We thank Jean-Yves Anctil, Denis Audet, Sophie Bérubé, Jean-Claude Dauvin, Manon Dumas, Michel Dubé, Robert Langevin, Hélene Marquis, Nathalie Martel and Bernard Massicotte for assistance in the field and lâboratory. This project was supported by grants from FCAR (Québec) and NSERC (Canada) to Julian J. Dodson and GIROQ (Groupe interuniversitaire de recherches Océanographiques du Québec). Réjean Laprise was funded by Department of Fisheries and Oceans Canada (Quebec region) and FCAR postgraduate scholarships.

\section{LITERATURE CITED}

Able, K. W. (1978). Ichthyoplankton of the St. Lawrence estuary: composition, distribution, and abundance. J. Fish. Res. Bd Can. 35: 1518-1531
Blaber, S. J. M., Blaber, T G. (1980). Factors affecting the distribution of juvenile estuanne and inshore fish. J. Fish Biol. 17: 143-162

Boehlert, G. W., Morgan, J. B. (1985). Turbidity enhances feeding abilities of larval Pacific herring. Clupea harengus pallasi. Hydrobiologia 123: 161-170

Bousfield, E. L., Filteaul, G. O'Neill, M., Gentes, P. (1975). Population dynamics of zooplankton in the middle St. Lawrence Estuary. Estuar. Res. 1: 325-351

Bruton, M. N. (1985). The effects of suspensoids on fish. Hydrobiologia 125: 221-241

Courtois, R., Simoneau, M., Dodson, J. J. (1982). Interactions multispécifiques: répartition spatio-temporelle des larves de capelan (Mallotus villosus), d'éperlan (Osmerus mordax) et de hareng (Clupea harengus harengus) au sein de la communauté planctonique de l'estuaire moyen du Saint-Laurent. Can. J. Fish. Aquat. Sci. 39: 1164-1174

D'Anglejan, B. (1981). On the advection of turbidity in the St. Lawrence middle estuary. Estuaries 4: 2-15

D'Anglejan, B., Ingram, R. G. (1976). Time-depth variations in tidal flux of suspended matter in the St. Lawrence estuary. Estuar. coast. mar. Sci. 4: 401-416

D'Anglejan, B., Smith, E. C. (1973). Distribution, transportation and composition of suspended matter in the St. Lawrence estuary. Can. J. Earth Sci. 10: 1380-1396

Dawson, W. B. (1917). Tide tables for the Eastern Coasts of Canada for the year 1918. Government Printing Bureau, Ottawa, Canada

De Wolf, L. (1973). On the retention of marine larvae in estuaries. Thalassia jugosl. 10: 415-424

Dodson, J. J., Dauvin, J.-C., Ingram, R. G., D'Anglejan, B. (1989). Abundance of larval rainbow smelt (Osmerus mordax) in relation to the maximum turbidity zone and associated macroplankton fauna of the Middle St. Lawrence Estuary. Estuaries 21. 66-81

El Sabh, M. I. (1988). Physical oceanography of the St. Lawrence Estuary. In: Kjerfve, B. (ed.) Hydrodynamics of estuaries. Vol. II, Estuarine case studies. CRC Press, Inc. Boca Raton, Florida, p. 61-78

Fortier, L., Legendre, L. (1979). Le contrôle de la variabilité à court terme du phytoplancton estuarien: stabilité verticale et profondeur critique. J. Fish. Res. Bd Can. 36: 1325-1335

Fortier, L., Leggett, W. C. (1982). Fickian transport and the dispersal of fish larvae in estuaries. Can. J. Fish Aquat. Sci. 39: $1150-1163$

Fréchet, A., Dodson, J. J., Powles, H. (1983). Use of variation in biological characters for the classification of anadromous rainbow smelt (Osmerus mordax) groups. Can. J. Fish Aquat. Sci. 40: 718-727

Hamming, R. W. (1977). Digital filters. Prentice-Hall, Englewood Cliffs, New Jersey

Kranck, K. (1979). Dynamics and distribution of suspended particulate matter in the St. Lawrence Estuary. Naturaliste Can. 106: 163-1.73

Legendre, L., Legendre, P. (1984). Ecologie numérique, Vol II Là structure des données écologique, 2nd edn. Masson and Presses de l'Université du Québec, Québec, Canada

Lucotte, M., D'Anglejan, B. (1986). Seasonal control of the St Lawrence maximum turbidity zone by tidal-flat sedimentation. Estuaries 9: 84-95

Markle, D. F. (1984). Phosphate buffered formalin for long term preservation of formalin fixed ichthyoplankton. Copeia 1984: 525-528

McCleave, J. D., Kleckner, R. C. (1982). Selective tidal stream transport in the estuarine migration of glass eel.s of the American eel (Anguilla rostrata). J. Cons. int. Explor. Mer 40: 262-271 
Neu, H. J. A. (1970). A study on mixing and circulation in the St. Lawrence Estuary up to 1964. Atlantic Oceanographic Laboratory, Bedford Institute, Report 1970-1979, 31

Neumann, G., Pierson, W. J. (1969). Principles of physical oceanography. Prentice-Hall, Englewood Cliffs, New Jersey

Norcross, B. L., Shaw, R. F. (1984). Oceanic and estuarine transport of fish eggs and larvae: a review. Trans. Am Fish. Soc. 113: 153-165

Ouellet, P., Dodson, J. J. (1985a). Dispersion and retention of anadromous rainbow smelt (Osmerus mordax) larvae in the middle estuary of the St. Lawrence River. Can. J. Fish. Aquat. Sci. 42: 332-341

Ouellet, P., Dodson, J. J. (1985b). Tidal exchange of anadromous rainbow smelt (Osmerus mordax) larvae between a shallow spawning tributary and the St. Lawrence Estuary. Can. J. Fish. Aquat. Sci. 42: 1352-1358

Ouellet, Y., Cerceau, J. (1976). Mélange des eaux douces et salées du Saint-Laurent, circulation et salinité. Les Cahiers de Centreau 1 (4): 1-57

Ouellet, Y., Trump, C. (1979). La circulation hydrodynamique dans la zone de mélange estuarienne du Saint-Laurent. Naturaliste can. 106: 13-26

Rogers, H. M. (1940). Occurrence and retention of plankton within the estuary. J. Fish. Res. Bd Can. 5: 154-171

Scherrer, B. (1984). Biostatistique. Gaëtan Morin éditeur, Chicoutimi, Canada

This article was submitted to the editor
Silverberg, N., Sundby, B. (1979). Observations in the turbidity maximum of the St. Lawrence estuary. Can. J. Earth Sci. 16: 939-950

Simoneau, M. (1986). Répartition spatio-temporelle et croissance des larves de capelan, d'éperlan et de hareng de l'Atlantique dans l'estuaire du Saint-Laurent. M. Sc. Thesis, Université Laval, Québec

Soucy, A., Bérubé, Y., Troude, J. P., Méric, P. (1976). Evolution des suspensions et des sédiments dans l'estuaire moyen du Saint-Laurent. Les Cahiers de Centreau, 1 (5): 1-67

Thrall, T., Engleman, L. (1985). Univariate and bivariate spectral analysis. In: Dixon, J. J. (ed.) BMDP statistical software. University of Calitornia Press, Berkeley, p. 604-638

Van Guelpen, L., Markle, D. F., Duggan, D. J. (1982). An evaluation of accuracy, precision and speed of several zooplankton subsampling techniques. J. Cons. int. Explor. Mer. 40: 226-236

Weinstein, M. P., Weiss, S. L., Hodson, R. G., Gerry, L. R. (1980). Retention of three taxa of postlarval fishes in an intensively flushed tidal estuary, Cape Fear River, North Carolina. Fish. Bull. U. S. 78: 419-436

Wippelhauser, G. S., McCleave, J. D. (1988). Precision and behavior of migrating juvenile american eels (Anguilla rostrata) utilizing selective tidal stream transport. J. Cons. int. Explor. Mer. 44: 80-89

Manuscript first received: October 7, 1988

Revised version accepted April 19, 1989 